DOI: $10.19195 / 0137-1134.113 .10$

\author{
ARTUR TOMANEK \\ Uniwersytet Wrocławski
}

\title{
PODMIOTY ODPOWIEDZIALNOŚCI PRACODAWCZEJ W STOSUNKACH PRAWA PRACY
}

\begin{abstract}
Abstrakt: Opracowanie koncentruje się wokół podmiotowej perspektywy odpowiedzialności pracodawcy w prawie pracy. Dotychczasowe wypowiedzi nauki prawa pracy wskazują, że odpowiedzialność za naruszenie obowiązków pracodawcy może być rozważana w szerokim znaczeniu, nieograniczającym się jedynie do podmiotu mającego status pracodawcy w rozumieniu definicji zamieszczonej w art. 3 k.p. Autor dokonuje przeglądu sytuacji prawnych wiążących się z ponoszeniem przez inne podmioty odpowiedzialności pracodawczej, koncentrując rozważania wokół sfery indywidualnych i zbiorowych stosunków pracy. Do podmiotów tych należą w szczególności: osoba prawna, w ramach której działa pracodawca wewnętrzny, Fundusz Gwarantowanych Świadczeń Pracowniczych, większościowy wspólnik spółki będącej pracodawcą. Sytuacje te mają charakter niejednorodny, co odzwierciedla się w ich kwalifikacji prawnej z rozważanego tutaj punktu widzenia. Oprócz przypadków, które mogą być zakwalifikowane jako odpowiedzialność pracodawcza, mamy do czynienia z ponoszeniem odpowiedzialności mającej charakter odrębny, co nie wyłącza jej jednak z zakresu rozważań nad odpowiedzialnością w prawie pracy.
\end{abstract}

Słowa kluczowe: pracodawca, odpowiedzialność pracodawcy

\section{PODMIOTOWA PŁASZCZYZNA ROZWAŻAŃ O ODPOWIEDZIALNOŚCI PRACODAWCY}

Pojęcie odpowiedzialności prawnej należy do podstawowych w prawoznawstwie. Jest ono też spotykane powszechnie w szczegółowych gałęziach prawa, zarówno w języku aktów normatywnych, jak i wypowiedziach doktrynalnych. Tej powszechności nie towarzyszy jednolitość pojmowania odpowiedzialności. Próby skonstruowania uniwersalnej definicji tego pojęcia są podejmowane w teorii prawa, natomiast przedstawiciele dyscyplin szczegółowych dostosowują je do potrzeb danego działu prawa, poprzestając niejednokrotnie na instrumentalnym ich używaniu, polegającym na wyodrębnianiu i nazywaniu poszczególnych rodzajów odpowiedzialności (karnej, kontraktowej, administracyjnej itp.).

Najbardziej znane ujęcie odpowiedzialności w prawoznawstwie polskim łączy się z definicją zaproponowaną przez W. Langa. Według tego autora odpowie- 
dzialność w najszerszym znaczeniu — zarówno na gruncie przepisów prawa, jak i nauki prawa - oznacza we wszystkich dyscyplinach prawniczych zasadę ponoszenia przewidzianych prawem ujemnych konsekwencji za zdarzenia lub stany rzeczy podlegające ujemnej kwalifikacji normatywnej i przypisywalne prawnie określonemu podmiotowi $\mathrm{w}$ danym porządku prawnym ${ }^{1}$.

Do pojęcia odpowiedzialności według W. Langa nawiązuje określenie odpowiedzialności w prawie pracy, zaprezentowane przez W. Sanetrę. Autor ten wskazał, że na odpowiedzialność prawa pracy składa się zasadniczo odpowiedzialność strony pracowniczej i pracodawczej. Odpowiedzialność każdej ze stron była jednak przez niego ujmowana węziej lub szerzej. Odnosząc się do odpowiedzialności pracowniczej, W. Sanetra stwierdził, że na jej węższe rozumienie składały się przewidziane w przepisach prawa pracy negatywne skutki (dolegliwości) o charakterze prawnym, które mogą być zastosowane wobec pracownika za jego naganne zachowanie. Wyróżnikiem odpowiedzialności w rozumieniu szerszym było to, że mogła być ona uregulowana również poza przepisami prawa pracy, a przewidziane $\mathrm{w}$ jej ramach dolegliwości miały w zasadzie charakter prawny (przy uwzględnieniu także sankcji pozaprawnych, z którymi może zetknąć się pracownik) i były związane jedynie w większości wypadków z nagannym zachowaniem się pracownika ${ }^{2}$.

Nadrzędne i szerokie pojęcie odpowiedzialności w prawie pracy, odnoszone do podmiotów występujących po stronie pracowniczej i pracodawczej, jak również pozostałych podmiotów prawa pracy, obejmujące również odpowiedzialność wewnętrzną, polegało zaś według W. Sanetry na nakładaniu przez podmioty lub organy usytuowane poza strukturą danego podmiotu, jak i w jego łonie, dolegliwości o charakterze majątkowym i niemajątkowym, których ustalenie opiera się na stwierdzeniu winy, wąsko ujętej bezprawności lub tylko na ogólnie sformułowanym prawnym zarzucie naganności zachowania się, zakwalifikowanym jako działanie w charakterze podmiotu prawa pracy, oraz pozostaje w związku z ob-

1 W. Lang, Struktura odpowiedzialności prawnej, „Zeszyty Naukowe Uniwersytetu Mikołaja Kopernika w Toruniu. Prawo" 1967, s. 12. Definicja ta stanowi punkt wyjścia licznych określeń formułowanych przez przedstawicieli szczegółowych nauk prawnych. Zob. T. Dybowski, [w:] System prawa cywilnego, t. 3, cz. 1. Prawo zobowiazań-część szczegółowa, red. Z. Radwański, Wrocław 1981, s. 167; T. Siemiątkowski, [w:] System Prawa Prywatnego, t. 16. Prawo spótek osobowych, red. A. Szajkowski, Warszawa 2008, s. 345-349; R. Paczuski, Prawo ochrony środowiska, Bydgoszcz 2000, s. 137.

2 W. Sanetra, O pojęciu i zakresie odpowiedzialności pracowniczej, [w:] Odpowiedzialność pracownicza. Materiaty XI Zimowej Szkoły Prawa Pracy, red. W. Sanetra, Wrocław 1984, s. 8; idem, Odpowiedzialność wedtug prawa pracy. Pojęcie, zakres, dyferencjacja, Wrocław 1991, s. 17; idem, Odpowiedzialność za naruszenie norm prawa pracy $w$ warunkach demokracji i spotecznej gospodarki rynkowej, [w:] Prawo pracy RP w obliczu przemian, red. M. Matey-Tyrowicz, T. Zieliński, Warszawa 2006, s. 306-307. 
ciążeniem podmiotów odpowiedzialnych sankcjami przewidzianymi głównie, ale nie tylko, w przepisach prawa pracy $^{3}$.

W latach siedemdziesiątych i osiemdziesiątych ubiegłego stulecia koncepcja W. Sanetry była przedmiotem ożywionej dyskusji naukowej, która ogniskowała się głównie wokół pojęcia odpowiedzialności pracowniczej ${ }^{4}$. W opozycji do tej koncepcji wskazywano, że odpowiedzialność ta powinna być ograniczona do przypadków dolegliwości stosowanych wobec pracownika, które zostały nazwane przez ustawodawcę mianem odpowiedzialności. Podnoszono również, że odpowiedzialność prawna nie może być odrywana od naruszenia obowiązku prawnego (normy prawnej) przez sprawcę naruszenia ${ }^{5}$. Zwłaszcza pojęcie odpowiedzialności pracowniczej uogólnia tylko pewien szczególny rodzaj sankcji, a więc ten, który wiąże się z nagannym zachowaniem się pracownika ${ }^{6}$.

Bliższe ustosunkowanie się do tego sporu wykracza poza ramy tego opracowania. Z dzisiejszej perspektywy wydaje się jednak, że szerokie ujęcie odpowiedzialności w prawie pracy odegrało pozytywną rolę. Trafne było oderwanie się przez W. Sanetrę od formalistycznego spojrzenia na problematykę odpowiedzialności, które eksponuje sytuacje określone tym mianem przez samego ustawodawcę. W kontekście podnoszonej tutaj problematyki szczególnie istotne znaczenie miało uwypuklenie przez powołanego autora podmiotowej płaszczyzny rozważań o odpowiedzialności pracodawcy. Przyjmował on, że przy konstruowaniu pojęcia odpowiedzialności jako kategorii całego prawa pracy, a nie tylko prawa stosunku pracy, najdogodniejszym podejściem jest takie, które pojęcie odpowiedzialności prawa pracy wiąże z wyróżnianymi podmiotami tego prawa ${ }^{7}$. Odnosząc się do strony pracodawczej, W. Sanetra rozróżniał między odpowiedzialnością węziej ujętą, w tym zwłaszcza w ramach indywidualnych stosunków pracy, którą określał jako odpowiedzialność pracodawcy. Wychodząc poza ścisłe ramy stosunku pracy,

3 W. Sanetra, Odpowiedzialność wedlug prawa pracy..., s. 37; idem, Odpowiedzialność za naruszenie..., s. 307-308.

${ }^{4}$ W dziedzinie odpowiedzialności pracowniczej występują — w odróżnieniu od odpowiedzialności pracodawcy — takie jej rodzaje (odpowiedzialność porządkowa, materialna itp.), które nie miały odpowiednika w innych dziedzinach prawa, co powodowało wzmożone zainteresowanie piśmiennictwa. Ponadto w istniejącej w PRL sytuacji, cechującej się sztuczną nadpodażą siły roboczej, istniał problem wyegzekwowania dyscypliny pracy środkami, które nie nosiły formalnie znamion odpowiedzialności pracowniczej. Rodziło skłonność doktryny do analizy stosowanych przez pracodawcę instrumentów polityki płacowej lub kadrowej w zakładzie pracy w kategoriach odpowiedzialności pracownika, po to by można było kształtować je w sposób zapewniający gwarancje ochrony interesów podmiotu odpowiedzialnego (pracownika). Por. W. Sanetra, Odpowiedzialność wedlug prawa pracy..., s. 21-22.

5 Z. Hajn, Odpowiedzialność prawna zakładu pracy w zbiorowych stosunkach pracy, [w:] Odpowiedzialność zbiorowych podmiotów prawa pracy. Materiaty XIV Zimowej Szkoły Prawa Pracy, red. W. Sanetra, Wrocław 1987, s. 28.

${ }^{6}$ Z. Masternak, Oceny w odpowiedzialności pracowniczej, [w:] Odpowiedzialność zbiorowych podmiotów..., s. 32.

7 W. Sanetra, Odpowiedzialność za naruszenie..., s. 307. 
używał on pojęcia „odpowiedzialność pracodawcza”. Z kolei odpowiedzialność szeroko ujmowanej strony pracodawczej obejmowała również sankcje adresowane do związków pracodawców ${ }^{8}$.

Niniejsze opracowanie zmierza do naświetlenia podmiotowej płaszczyzny odpowiedzialności z tytułu ujemnie kwalifikowanych działań i zaniechań pracodawcy. Rozważania koncentruję zasadniczo wokół sfery indywidualnych i zbiorowych stosunków pracy. Przedmiotem uwagi jest sytuacja podmiotów innych niż pracodawca w rozumieniu art. 3 k.p., którym można przypisać odpowiedzialność prawną oprócz lub zamiast pracodawcy, obejmującą poniesienie konsekwencji z tytułu naruszenia obowiązków odnoszonych do tej strony stosunków prawnych, po której występuje pracodawca. Powstaje pytanie, czy odpowiedzialność ta mieści się $\mathrm{w}$ ramach odpowiedzialności pracodawcy bądź w szerszej kategorii odpowiedzialności prawa pracy, zachodzącej po pracodawczej stronie stosunków prawa pracy, którą określam jako odpowiedzialność pracodawczą. Do oznaczenia podmiotów ponoszących taką odpowiedzialność używam terminu ,podmioty odpowiedzialności pracodawczej”. Odpowiedzi na postawione pytanie służy dokonany tu niewyczerpujący przegląd przypadków odpowiedzialności ponoszonej przez różnego rodzaju podmioty. Poza zakresem rozważań pozostawiam natomiast zagadnienia związane z odpowiedzialnością organizacji pracodawców, których ustrój i zadania są regulowane odrębnym aktem prawnym ${ }^{9}$.

Z punktu widzenia podjętej tutaj tematyki wymaga zaznaczenia, że w teorii prawa, jak też w szczegółowych naukach prawnych, sporne jest, czy w ramach pojęcia odpowiedzialności prawnej mieści się dochodzenie przez wierzyciela przymusowego spełnienia świadczenia wynikającego z pierwotnego obowiązku dłużnika (na przykład dochodzenie przez pracownika zapłaty wynagrodzenia za pracę), jak wskazuje się w niektórych wypowiedziach doktryny ${ }^{10}$. W uzasadnieniu odmiennego poglądu podkreślono, że zmuszenia do wypełnienia obowiązku nie można traktować jako odpowiedzialności, ponieważ przymus państwowy zmierza do wypełnienia obowiązku już istniejącego ${ }^{11}$. Odpowiedzialność jest zatem związana z obowiązkiem wtórnym, stanowiącym sankcję za naruszenie obowiązku pierwotnego ${ }^{12}$. W kwestii rozważań o podmiotowym zakresie odpowiedzialności pracodawczej bardziej konstruktywne wydaje się przyjęcie pierwszego z wymienionych założeń. Odpowiedzialność innych niż pracodawca podmiotów, wynika-

8 W. Sanetra, Odpowiedzialność wedtug prawa pracy..., s. 355.

${ }^{9}$ Ustawa z dnia 23 maja 1991 r. o organizacjach pracodawców (tekst jedn. Dz.U. z 2015 r. poz. 2029).

10 Tak między innymi A. Klein, Wykonanie umowy i odpowiedzialność, [w:] Instytucje prawne $w$ gospodarce narodowej, red. L. Bar, Wrocław 1981, s. 282-283; A. Stelmachowski, Wstęp do teorii prawa cywilnego, Warszawa 1984, s. 314.

11 R.O. Chałfina, Ogólna nauka o stosunku prawnym, Warszawa 1979, s. 325.

12 W. Radecki, Odpowiedzialność prawna w ochronie środowiska, Warszawa 2002, s. 61. Natomiast na tle stosunków prawa cywilnego T. Siemiątkowski (op. cit., s. 358) dokonał rozróżnienia między odpowiedzialnością cywilnoprawną a odpowiedzialnością za dług własny lub cudzy. 
jąca z naruszenia obowiązków, które odnoszone jest najpierw do pracodawcy, ma bowiem zwykle charakter dodatkowy lub subsydiarny w stosunku do obowiązków samego pracodawcy. Istotnym argumentem jest też treść tych przepisów prawa, które używają w omawianych dalej sytuacjach terminu „odpowiedzialność”"13 lub „odpowiadać”"14.

Prima facie oczywiste wydaje się stwierdzenie, że podmiotem ponoszącym negatywne konsekwencje ujemnie kwalifikowanych działań pracodawcy w stosunkach prawa pracy jest (i powinien być) sam podmiot zatrudniający. Bliższy ogląd tej problematyki wskazuje jednak na znacznie większy stopień jej skomplikowania, co wynika z oddziaływania kilku czynników. Po pierwsze, definicja zamieszczona $\mathrm{w}$ art. 3 k.p., stanowiąca punkt wyjścia formułowania pojęcia pracodawcy w ramach prawa pracy, wykazuje znaczne odchylenia od określeń podmiotowości prawnej funkcjonujących $\mathrm{w}$ innych dziedzinach prawa, a zwłaszcza w prawie cywilnym, nadając zdolność pracodawczą wewnętrznym jednostkom organizacyjnym osób prawnych, pozbawionym zdolności prawnej poza stosunkami prawa pracy (tak zwanym wewnętrznym pracodawcom), co stawia na porządku dziennym kwestię ponoszenia odpowiedzialności majątkowej za zobowiązania zaciągane przez tak określonych pracodawców. Po wtóre, liczne zmiany organizacyjno-prawne i przekształcenia zachodzące po stronie pracodawców implikują włączenie do kręgu podmiotów odpowiedzialnych za zobowiązania pracownicze różnego rodzaju osób i jednostek organizacyjnych. Zjawisko zaś niewypłacalności podmiotu zatrudniającego wiąże się ze stworzeniem systemu gwarantowanych roszczeń pracowniczych. Po trzecie, złożoność współczesnych form organizacji działalności gospodarczej powoduje, że podmiot będący pracodawcą może być elementem bardziej rozbudowanej organizacji, takiej jak koncern, holding lub grupa spółek, w ramach której znajduje się centrum podejmowania decyzji i zasadniczy zasób majątkowy związany z prowadzoną działalnością. Kwestie te zostaną rozwinięte $w$ dalszej części rozważań.

\section{ODPOWIEDZIALNOŚĆ ZA ZOBOWIĄZANIA PRACODAWCY WEWNĘTRZNEGO}

Status pracodawcy wewnętrznego (na przykład oddziału spółki handlowej albo gminnej lub państwowej jednostki organizacyjnej) nie prowadzi do podmiotowości takiej jednostki w stosunkach cywilnoprawnych. Tak określony pracodawca nie jest zatem podmiotem praw majątkowych pozwalających na zaspokojenie pracownika lub innego wierzyciela przedstawiającego tytuł wykonawczy. Zauważalny jest niedostatek umocowania prawnego odpowiedzialności za te zobowiązania,

\footnotetext{
13 Zob. np. art. $55^{4}$ k.c., art. $22 \S 2$ k.s.h. w zw. z art. $31 \S 1$ k.s.h.

14 Zob. art. $23^{1} \S 2$ k.p.
} 
rozumianej jako zdolność do ich przymusowego zaspokojenia. W piśmiennictwie sformułowano kategorię cząstkowej zdolności prawnej jednostki organizacyjnej do bycia podmiotem praw i obowiązków wynikających ze stosunku pracy. Stwierdzono jednocześnie, odwołując się między innymi do art. 460 § 1 k.p.c. i art. 778 k.p.c., że jeśli pracownik nie może wyegzekwować od tej jednostki swojej należności, to odpowiedzialność powinna ponosić osoba prawna, której ta jednostka jest częścią, lub osoby ją tworzące ${ }^{15}$. Według innego stanowiska możliwe jest odpowiednie stosowanie przepisu art. $33^{1} \S 2$ k.c., określającego przesłanki odpowiedzialności subsydiarnej członków jednostki organizacyjnej nieposiadającej osobowości prawnej, której ustawa przyznaje zdolność prawną (osoby ustawowej) ${ }^{16}$. Z kolei wykładnia sądowa przyjmuje, bez wskazania podstawy prawnej, że jeśli pracodawca jest częścią osoby prawnej, to za zobowiązania wobec pracowników osoba ta ponosi odpowiedzialność całym swoim majątkiem. Wyodrębnienie finansowe pracodawcy wewnętrznego jest zatem tylko zabiegiem wewnątrzorganizacyjnym tej osoby prawnej, niemającym wpływu na jej majątkową odpowiedzialność wobec wierzycieli-pracowników ${ }^{17}$.

Żadna $\mathrm{z}$ tych koncepcji nie jest w pełni zadowalająca. Ujawniają one deficyt podstawy prawnej odpowiedzialności za zobowiązania pracodawcy wewnętrznego $^{18}$, zwłaszcza gdy jest on usytuowany poza strukturą Skarbu Państwa lub gminy (na przykład jako oddział spółki kapitałowej). Niezależnie jednak od braków tych koncepcji nie da się zaprzeczyć racjonalności ich wniosków, albowiem inaczej nikt nie ponosiłby odpowiedzialności za zobowiązania majątkowe pracodawcy wewnętrznego.

W literaturze prawa pracy wskazano trafnie, że rezultatem tych wykładni jest rozdzielenie podmiotowości pracodawcy wewnętrznego od odpowiedzialności prawnej za jego zobowiązania, ponoszonej przez inny podmiot, którym jest „,macierzysta" dla tego pracodawcy osoba prawna ${ }^{19}$. Jest to jednak podmiot „stojący” bezpośrednio za pracodawcą, ze względu na oczywiste, organizacyjno-prawne powiązania między osobą prawną a jej wewnętrzną jednostką organizacyjną. Odpowiedzialność osoby prawnej za zobowiązania pracodawcy wewnętrznego powinna być zatem rozważana w ramach odpowiedzialności pracodawczej.

15 J. Frąckowiak, Jednostka organizacyjna jako podmiot stosunku pracy, [w:] Z zagadnień prawa pracy i prawa socjalnego. Księga jubileuszowa Profesora Herberta Szurgacza, red. Z. Kubot, T. Kuczyński, Warszawa 2011, s. 102-104.

16 P. Czarnecki, Odpowiedzialność pracodawcy a rozwój struktur holdingowych, Warszawa 2014, s. 137-140.

17 Wyrok SN z dnia 19 maja 2016 r., II PK 100/15, LEX nr 2056868.

18 Trudno zaakceptować odwołanie się do art. $460 \S 1$ k.p.c., art. 778 k.p.c. lub art. $33^{1}$ k.c., które dotyczą kwestii innych niż odpowiedzialność prawna za zobowiązania pracodawcy wewnętrznego w ujęciu art. 3 k.p.

19 Z. Hajn, [w:] System Prawa Pracy, t. 2. Indywidualne prawo pracy, red. G. Goździewicz, Warszawa 2017, s. 174; P. Czarnecki, op. cit., s. 132. 
Nie może też ujść uwagi, że kodeksowe określenie pracodawcy nie jest jedynym spotykanym w ustawowych przepisach prawa pracy. W szczególności na gruncie art. 2 ust. 1 ustawy z dnia 13 lipca 2006 r. o ochronie roszczeń pracowniczych w razie niewypłacalności pracodawcy (u.o.r.p. ${ }^{20}$ pracodawca jest definiowany jako przedsiębiorca, o którym mowa w art. 4 ust. 1 ustawy z dnia 2 lipca 2004 r. o swobodzie działalności gospodarczej. Poza zakresem tej definicji pozostaje więc pracodawca wewnętrzny w rozumieniu art. 3 k.p. Należy zatem uznać, że pracodawcą w rozumieniu tej ustawy jest osoba prawna, której częścią jest pracodawca wewnętrzny ${ }^{21}$. O ile zatem pracodawca ten korzysta generalnie $\mathrm{z}$ podmiotowości w prawie pracy, o tyle w stosunkach prawnych związanych z zaspokojeniem roszczeń pracowniczych przez insty tucję gwarancyjną podmiotowość przysługuje wyłącznie osobie prawnej stojącej za takim pracodawcą. Odpowiedzialność prawna wynikająca $\mathrm{z}$ realizacji obowiązków określonych w u.o.r.p. jest zatem przypisywana bezpośrednio osobie prawnej macierzystej dla pracodawcy wewnętrznego.

Niezależnie od tego odrębną płaszczyzną odpowiedzialności osoby prawnej, której ogniwem są jednostki organizacyjne będące pracodawcami, mogą być zbiorowe stosunki pracy. Osoba prawna ma bowiem zdolność do zawarcia zakładowego układu zbiorowego obejmującego pracodawców wchodzących w skład tej osoby (art. $241^{28} \S 1$ i 2 k.p. $)^{22}$. Z tego względu na osobie tej spoczywają obowiązki wynikające z prowadzenia negocjacji układowych i zawarcia układu oraz związana $\mathrm{z}$ tymi obowiązkami odpowiedzialność w sferze zbiorowych stosunków pracy.

\section{ODPOWIEDZIALNOŚĆ PODMIOTÓW WYSTĘPUJĄCYCH PO STRONIE PRACODAWCY W RAZIE JEGO PRZEKSZTAŁCEŃ ORGANIZACYJNO-PRAWNYCH}

Przypisanie podmiotowi innemu niż pracodawca odpowiedzialności za zobowiązania wynikające $\mathrm{z}$ indywidualnego stosunku pracy może nastąpić w wy-

20 Tekst jedn. Dz.U. z 2016 r. poz. 1256, ze zm.

$21 \mathrm{~W}$ piśmiennictwie zauważono, że według literalnej treści art. 2 ust. 1 u.o.r.p. osoba prawna, której ogniwem jest pracodawca wewnętrzny, nie ma w rozumieniu tego przepisu statusu pracodawcy w stosunku do pracowników pracodawcy wewnętrznego. Zob. M. Latos-Miłkowska, Ochrona roszczeń pracowniczych w razie niewypłacalności pracodawcy. Komentarz, Warszawa 2017, s. 31. Systemowa i celowościowa wykładnia przepisów u.o.r.p. prowadzi jednak, moim zdaniem, do jedynego racjonalnego wniosku, że w rozpatrywanej sytuacji osoba prawna ma status pracodawcy w rozumieniu u.o.r.p. W przeciwnym razie roszczenia pracowników zatrudnionych przez jednostkę organizacyjną w rozumieniu art. 3 k.p., istniejącą w ramach niewypłacalnej osoby prawnej, byłyby niezasadnie wyłączone z systemu gwarantowanych roszczeń pracowniczych.

22 Wbrew dosłownemu brzmieniu przytoczonego przepisu wydaje się, że podmiotem prowadzącym rokowania i zawierającym układ jest osoba prawna, a nie jej organ, który może działać jedynie za osobę prawną, a nie we własnym imieniu. Tak trafnie K. Rączka, [w:] Kodeks pracy. Komentarz, M. Gersdorf, K. Rączka, M. Raczkowski, Warszawa 2014, uw. 6 do art. $241^{28}$ k.p. 
niku przepisu ustawy lub czynności prawnej. Skupiając się tu na mechanizmach ustawowych, należy stwierdzić, że rozwiązania takie wynikają zwykle z potrzeby zapewnienia pracownikowi ochrony przed niezaspokojeniem jego roszczeń przez podmiot aktualnie go zatrudniający. Poszerzenie podmiotowego zakresu odpowiedzialności jest przewidywane zarówno w przepisach prawa pracy, jak i w regulacjach leżących poza zakresem tej gałęzi prawa. W przypadku norm prawa pracy na pierwszy plan wysuwa się instytucja przejścia zakładu pracy na innego pracodawcę (art. $23^{1}$ k.p.). Przeniesienie zakładu pracy w całości skutkuje sukcesją nowego pracodawcy w treść dotychczasowych stosunków pracy, obejmującą też przejęcie odpowiedzialności za zobowiązania zaciągnięte wobec przejętych pracowników przez poprzedniego pracodawcę. Przejście części zakładu pracy powoduje natomiast sukcesję ograniczoną do pracowników zatrudnionych $\mathrm{w}$ jednostce będącej przedmiotem transferu, a dotychczasowy podmiot zatrudniający pozostaje, po przejściu, odpowiedzialny solidarnie z nowym pracodawcą za zobowiązania ze stosunku pracy, które powstały przed tym zdarzeniem (art. $23^{1} \S 2$ k.p.).

$\mathrm{Z}$ istoty sukcesji podmiotowej w stosunkach pracy wynika, że pracodawca przejmujący zakład pracy lub jego część odpowiada za zobowiązania wynikające ze stosunków pracy objętych sukcesją, to znaczy istniejących w dniu przejścia ${ }^{23}$. Orzecznictwo sądowe opowiada się jednak za rozszerzeniem zakresu sukcesji podmiotu przejmującego w przypadkach, gdy przejęciu zakładu pracy towarzyszy likwidacja pracodawcy dotychczasowego. Przyjęto zatem, wykładnią art. $23^{1}$ $\S 1$ i 2 k.p., że dotychczasowy i nowy pracodawca odpowiadają in solidum za zobowiązania wobec pracowników zwolnionych przed dniem przejścia względnie odpowiedzialność za te zobowiązania, z braku odmiennych uregulowań prawnych, ponosi wyłącznie nowy podmiot zatrudniający $\mathrm{w}$ razie zlikwidowania poprzedniego pracodawcy ${ }^{24}$. Przyznaje się też pracownikowi możliwość dochodzenia od podmiotu przejmującego roszczeń restytucyjnych lub odszkodowawczych wynikających z rozwiązania stosunku pracy przed datą przejścia zakładu pracy (lub jego części), gdy ustanie stosunku pracy nastąpiło z powodu tego przejścia ${ }^{25}$.

Taki sposób przypisania odpowiedzialności podmiotowi, który nie stał się pracodawcą osoby mającej roszczenie wobec dotychczasowego podmiotu zatrudniającego, nosi jednak znamiona wyjątkowości. Dokonana w tym celu wykładnia jest zbędna, jeżeli istnieje odrębna podstawa rozszerzenia podmiotowego zakresu odpowiedzialności w związku z przejściem zakładu pracy albo innym przekształceniem organizacyjno-prawnym powodującym zmianę pracodawcy. Podstawą tą

23 Ł. Pisarczyk, Przejście zakładu pracy na innego pracodawcę, Warszawa 2013, s. 196; A. Tomanek, Przejście zakładu pracy na innego pracodawce, Wrocław 2002, s. 140-145.

${ }^{24}$ Zob. uzasadnienie uchwały SN z dnia 7 lipca 2000 r., III ZP 16/00, OSNP 2000, nr 23, poz. 847.

25 Wyrok SN z dnia 16 maja 2001 r., I PKN 573/00, OSNP 2003, nr 5, poz. 124; wyrok SN z dnia 10 września 2004 r., I PK 449/03, OSNP 2005, nr 9, poz. 127. 
może być przepis prawa, akt administracyjny, czynność prawna lub inne zdarzenie prawne ${ }^{26}$.

Wśród przepisów prawa należy wymienić regulacje przejściowe zamieszczone $\mathrm{w}$ aktach prawnych wprowadzających zmiany strukturalne w aparacie administracji publicznej, w których wyniku dochodziło do przejęcia zakładu pracy, prowadzonego w formie jednostki budżetowej Skarbu Państwa, przez samorządową jednostkę organizacyjną, która wstępowała wobec tego w prawa i obowiązki pracodawcy. Przepis art. 80 ust. 1 ustawy z dnia 13 października 1998 r. - Przepisy wprowadzające ustawy reformujące administrację publiczną ${ }^{27}$ wskazywał, że Skarb Państwa odpowiada za powstałe przed dniem przekształcenia zobowiązania państwowych jednostek budżetowych i zakładów budżetowych, przejmowanych przez jednostki samorządu terytorialnego. Mając na względzie odrębność podstaw odpowiedzialności Skarbu Państwa oraz nowego pracodawcy (art. $23^{1}$ k.p.), w orzecznictwie przyjęto, że podmioty te odpowiadają in solidum za zobowiązania wynikające ze stosunku pracy ${ }^{28}$. Odpowiedzialność Skarbu Państwa może być rozpatrywana jako formuła odpowiedzialności osoby prawnej za zobowiązania zaciągnięte przez pracodawcę wewnętrznego, o czym była mowa w poprzedniej części rozważań.

W wypadku zmian organizacyjno-prawnych dotyczących przedsiębiorców można wskazać na przepis art. $584^{13}$ k.s.h., który reguluje skutki przekształcenia formy działalności gospodarczej prowadzonej przez przedsiębiorcę będącego osobą fizyczną w jednoosobową spółkę kapitałową. Przepis ten przewiduje solidarną ze spółką odpowiedzialność osoby fizycznej (przedsiębiorcy przekształcanego)

26 Zob. uzasadnienie wyroku SN z dnia 25 kwietnia 2017 r., II PK 73/16, LEX nr 2329024. Orzeczenie to zostało wydane na tle uchwały rady gminy, przewidującej przejęcie przez gminę należności i zobowiązań zlikwidowanej jednostki budżetowej, gdy prowadzony przez tę jednostkę zakład pracy został przejęty przez inny podmiot. Uzasadniało to odpowiedzialność gminy za ów zakres zobowiązań, wynikających ze stosunków pracy, niezależnie od jednoczesnej odpowiedzialności ponoszonej na podstawie art. $23^{1} \S 1$ k.p. przez podmiot przejmujący zakład pracy.

27 Dz.U. Nr 133, poz. 872, ze zm.

28 Przyjmowano w szczególności, że podstawą odpowiedzialności Skarbu Państwa za zobowiązania pracownicze jest art. 80 ust. 1 ustawy z dnia 13 października 1998 r. albo że przepis ten jedynie potwierdza regułę, zgodnie z którą zobowiązania związane z działalnością państwowej jednostki organizacyjnej, niemającej osobowości prawnej, po włączeniu jej w strukturę innej osoby prawnej, pozostają nadal zobowiązaniami Skarbu Państwa, jeżeli co innego nie wynika ze szczególnego przepisu ustawy Zob. wyrok SN z dnia 18 grudnia 2002 r., I PKN 668/01, OSNP 2004, nr 3, poz. 47; a także wyrok SN z dnia 24 lipca 2008 r., IV CSK 164/08, LEX nr 452998, oraz powołane w nim dalsze orzecznictwo tego Sądu, które odnosiło się przede wszystkim do odpowiedzialności Skarbu Państwa za zobowiązania zakładu opieki zdrowotnej-jednostki budżetowej przed jego przekształceniem w samodzielny publiczny zakład opieki zdrowotnej. Kwestii tej dotyczył też wyrok Trybunału Konstytucyjnego z dnia 4 kwietnia 2005 r., SK 7/03 (OTK-A 2005, nr 4, poz. 34), według którego art. $23^{1}$ k.p. w zakresie, w jakim pomija współodpowiedzialność Skarbu Państwa za zobowiązania wynikające ze stosunku pracy powstałe przed przekształceniem statio fisci Skarbu Państwa — zakładu opieki zdrowotnej w samodzielny publiczny zakład opieki zdrowotnej, jest niezgodny z art. 32 ust. $1 \mathrm{w}$ zw. $\mathrm{z}$ art. 64 ust. 2 Konstytucji RP. 
za zobowiązania tej osoby związane z prowadzoną działalnością gospodarczą, powstałe przed dniem przekształcenia, która utrzymuje się przez okres trzech lat, poczynając od tego dnia ${ }^{29}$. Odnosząc to rozwiązanie do stosunku pracy, należy stwierdzić, że odpowiedzialność za zobowiązania powstałe przed przekształceniem ponosić będzie nie tylko nowy pracodawca (spółka), lecz także — w okresie przejściowym - dotychczasowy podmiot zatrudniający (osoba fizyczna).

Warto też zatrzymać się nad regulacją art. $55^{4}$ k.c., która ma ogólniejsze znaczenie i inny zakres zastosowania. Jak wskazano, skutki przejścia zakładu pracy na innego pracodawcę (art. $23^{1}$ k.p.) nie obejmują, co do zasady, stosunków pracy rozwiązanych przed datą przejścia oraz wynikających z tych stosunków zobowiązań pracodawcy. Jeżeli jednak przedmiotem przejęcia jest przedsiębiorstwo lub zakład, to przepis art. $55^{4}$ k.c., stosowany w związku z art. 300 k.p., będzie uzasadniał, według uregulowanych w nim zasad, ograniczoną przedmiotowo odpowiedzialność nabywcy za ów zakres zobowiązań pracodawcy (zbywcy). Wówczas odpowiedzialność nabywcy dotyczy długu formalnie własnego, ale materialnie cudzego.

Powstaje pytanie, czy wymienione konstrukcje prawne, prowadzące do przypisania - w związku z przejściem zakładu pracy lub innymi procesami przekształceniowymi — odpowiedzialności ze stosunku pracy podmiotowi innemu niż pracodawca, mogą być rozważane w ramach kategorii pojęciowej odpowiedzialności pracodawczej. Ze względu na zróżnicowaną paletę tych rozwiązań trudno mówić o jednolitej regule. Do odpowiedzialności pracodawcy sensu stricto można zaliczyć, moim zdaniem, odpowiedzialność ponoszoną przez dotychczasowego lub nowego pracodawcę w związku z zastosowaniem art. $23^{1} \mathrm{k}$.p. W pozostałych przypadkach mamy do czynienia $\mathrm{z}$ dodatkową odpowiedzialnością innych niż pracodawca podmiotów, opartą na regulacjach pochodzących spoza gałęzi prawa pracy. Niemniej jednak wynikająca z tych przepisów odpowiedzialność wykazuje bliskie powiązania z odpowiedzialnością pracodawcy, jeżeli przypisuje się ją osobie, której przysługiwały uprawnienia właścicielskie w stosunku do majątku podmiotu zatrudniającego.

\section{ODPOWIEDZIALNOŚĆ INSTYTUCJI GWARANCYJNEJ W RAZIE NIEWYPŁACALNOŚCI PRACODAWCY}

Stosownie do art. 12 ust. 1 ustawy o ochronie roszczeń pracowniczych w razie niewypłacalności pracodawcy określone przez tę ustawę roszczenia pracowników, byłych pracowników oraz uprawnionych do renty rodzinnej członków ich rodzin

29 Dłużnik będący osobą fizyczną ponosi solidarną odpowiedzialność na podstawie art. $584^{13}$ k.s.h., jeżeli wierzyciel wytoczy przeciwko niemu powództwo w okresie biegu terminu trzyletniego, określonego w tym przepisie (uchwała SN z dnia 9 lutego 2017 r., III CZP 113/16, OSNC 2018, nr 1, poz. 1). 
są zaspokajane z Funduszu Gwarantowanych Świadczeń Pracowniczych (dalej: Fundusz) w razie zaistnienia stanu niewypłacalności pracodawcy, zdefiniowanego w przepisach tej ustawy. Świadczenia te są wypłacane przez Fundusz po przedstawieniu przez pracodawcę zbiorczego wykazu niezaspokojonych roszczeń pracowniczych bądź w razie zgłoszenia indywidualnego wniosku pracownika lub innego uprawnionego. Spory powstałe w związku z odmową wypłaty świadczenia ze środków Funduszu rozpoznaje sąd właściwy w sprawach z zakresu prawa pracy (art. 20 ust. 2 u.o.r.p.).

Wypłata świadczenia ze środków Funduszu wymaga spełnienia tych samych przesłanek, które muszą być zrealizowane w celu nabycia przez pracownika prawa do wynagrodzenia, odprawy lub innego świadczenia należnego od niewypłacalnego pracodawcy. Spełnienie świadczenia ze środków Funduszu jest jednoznaczne z zaspokojeniem pracownika do granic określonych przez wysokość wypłaty. W doktrynie zauważono, że skoro dług pracodawcy wobec pracownika ma charakter zobowiązaniowy, to taki sam charakter należy przyznać roszczeniom osób uprawnionych wobec Funduszu, a stosunki prawne powstające w trakcie wypłaty świadczeń powinny mieć charakter stosunków prawa pracy. Obowiązek zaspokojenia pracownika ze środków Funduszu wynika z odpowiedzialności typu gwarancyjnego, gdyż jest on uzależniony od istnienia i wysokości wierzytelności pracownika wobec niewypłacalnego pracodawcy ${ }^{30}$.

Podzielając charakterystykę relacji prawnych łączących Fundusz z osobą uprawnioną, należy uznać, że odpowiedzialność ponoszona przez Fundusz jest akcesoryjna wobec odpowiedzialności pracodawcy w stosunku do pracownika ${ }^{31}$. Rozważany tutaj reżim odpowiedzialności nie może być uznany za odpowiedzialność pracodawcy. Fundusz jest państwową osobą prawną, która nie jest powiązana $\mathrm{z}$ niewypłacalnym pracodawcą, a jego upoważnienie do działania w stosunkach prawa pracy wynika z przepisów prawa publicznego. Ponadto spełnienie świadczenia ze środków Funduszu nie zwalnia pracodawcy z odpowiedzialności. Zmienia się jedynie wierzyciel niewypłacalnego podmiotu zatrudniającego, ponieważ w miejsce pracownika wstępuje Fundusz, na zasadzie art. 23 ust. 1 u.o.r.p., który stanowi, że przekazanie środków finansowych Funduszu na wypłatę świadczeń dla pracowników, a także wypłata tych świadczeń ze środków Funduszu, powoduje przejście na podmiot działający w imieniu dysponenta Funduszu roszczenia wobec pracodawcy lub osoby zarządzającej jego majątkiem albo roszczenia do masy upadłości o zwrot wypłaconych świadczeń.

Niezależnie od wadliwego sformułowania art. 23 ust. 1 u.o.r.p. ${ }^{32}$ przepis ten bez wątpienia przewiduje odpowiedzialność pracodawcy. Jest to jednak odpowiedzialność pracodawcy nie wobec pracownika, lecz wobec Funduszu. Mimo

30 Por. M. Gersdorf, Niewyplacalność pracodawcy w prawie pracy, Warszawa 2002, s. 164-170.

31 Ibidem, s. 170.

32 Zob. więcej A. Tomanek, Stosunki pracy w razie likwidacji i upadłości pracodawcy, Warszawa 2012, s. 337. 
przemieszania $\mathrm{w}$ treści tego przepisu elementów wskazujących na autonomiczny charakter roszczenia Funduszu (mówi się tam o roszczeniu o zwrot wypłaconego świadczenia) oraz określeń charakteryzujących mechanizm cessio legis, należy przyjąć, że Fundusz dochodzi od pracodawcy zwrotu własnego świadczenia wydatkowanego na zaspokojenie roszczeń pracowniczych. Znamienne jest ponadto, że $w$ art. 23 ust. 3 u.o.p.r. przewidziano możliwość odstąpienia od dochodzenia lub umorzenia należności zwrotnej wobec pracodawcy, nawet wbrew woli dysponenta Funduszu $^{33}$, co odbiega od modelu relacji łączącej dłużnika i wierzyciela w ramach typowej konstrukcji cessio legis.

W piśmiennictwie wskazano trafnie, że stosunek prawny, jaki zawiązuje się między niewypłacalnym pracodawcą a Funduszem po zrealizowaniu przez Fundusz świadczeń, do których zobowiązany był pracodawca, ma charakter zobowiązania prawa cywilnego ${ }^{34}$. Dodatkowym argumentem na rzecz takiej oceny jest, że odpowiedzialność podmiotu zatrudniającego wobec Funduszu może powstać również w razie zaspokojenia z jego środków roszczeń wykonawców umów cywilnoprawnych ${ }^{35}$. Nie przeczy temu treść art. 23 ust. 2 u.o.r.p., według którego przy dochodzeniu zwrotu wypłaconych świadczeń roszczenia należne Funduszowi korzystają z takiej samej ochrony prawnej jak należności za pracę. Przyznanie roszczeniu Funduszu tak wysokiego standardu ochrony nie ma bowiem na celu zrównania go z roszczeniem pracownika, lecz zapewnienie mu takich samych ułatwień, z których korzysta pracownik przy dochodzeniu od pracodawcy świadczeń majątkowych ze stosunku pracy.

\section{ODPOWIEDZIALNOŚĆ PODMIOTÓW POWIĄZANYCH KAPITAŁOWO Z PRACODAWCA}

O podmiotach powiązanych kapitałowo z pracodawcą możemy mówić w sektorze gospodarczym przede wszystkim w wypadku spółek handlowych zatrudniających pracowników. W ramach tego zagadnienia wyróżniam dwa jego aspekty. Pierwszy wiąże się z ustanowionymi w przepisach prawa normami, z których wynika reżim prawny odpowiedzialności określonych osób za zobowiązania podmiotu zatrudniającego. Aspekt drugi zaś ujawnia się w sytuacji przeciwnej, w której brakuje takiego reżimu prawnego, natomiast dostrzega się potrzebę nadania efektom oddziaływania więzi kapitałowych znaczenia prawnego w stosunkach prawa pracy, jeżeli więzi te, a nie zdefiniowany kodeksowo pracodawca (konkretna spółka), mają decydujący wpływ na kształt i treść tych stosunków.

33 Zob. wyrok SN z dnia 27 lipca 2006 r., III CSK 88/06, OSP 2007, nr 7-8, poz. 89.

34 M. Gersdorf, op. cit., s. 90, 168-169.

35 Roszczenia wynikające z umów prawa cywilnego, określonych w art. 10 u.o.r.p., są objęte gwarancjami zaspokojenia ze środków Funduszu. 
Pierwszy ze wskazanych aspektów wiąże się z odpowiedzialnością dodatkową (uzupełniającą) proklamowaną w przepisach ustrojowych odnoszących się do poszczególnych osób prawnych. Przykładem jest regulacja art. 22 § k.s.h., według której wspólnik spółki jawnej ponosi subsydiarną i solidarną ze spółką odpowiedzialność za jej zobowiązania ${ }^{36}$. Subsydiarność oznacza, że wierzyciel spółki jest uprawniony do wszczęcia egzekucji z majątku wspólnika, dopiero gdy egzekucja z majątku spółki okaże się bezskuteczna (art. 31 § 1 k.s.h.). Spółka jawna ma zdolność pracodawczą, podobnie jak pozostałe typy osobowych spółek handlowych, do których stosuje się wskazane przepisy kodeksu spółek handlowych ${ }^{37}$. Omawiana regulacja obejmuje roszczenia wobec spółki wynikające ze stosunków prawnych o charakterze zobowiązaniowym, nie wyłączając stosunku pracy. Pracownik może zatem pociągnąć wspólnika spółki jawnej będącej pracodawcą do odpowiedzialności subsydiarnej. Jest to jednak odpowiedzialność prawa handlowego (prawa spółek), nie zaś prawa pracy. Mając to na względzie, w omawianym przypadku nie można mówić o odpowiedzialności pracodawczej, ale o odpowiedzialności subsydiarnej ponoszonej przez inny podmiot prawa ${ }^{38}$.

Aspekt drugi nawiązuje do sytuacji, w których rzeczywisty decydent, będący wspólnikiem, „ukrywa się" za formą prawną spółki-pracodawcy, co nie pozwala dostrzec w jego działaniach czynności podmiotu zatrudniającego. Praktyka cechuje się w tym zakresie znaczną różnorodnością. W niektórych przypadkach chodzi o to, czy czynność wspólnika może być traktowana jako akt woli pracodawcy, wpływając w ten sposób na treść stosunków pracy. W innych sytuacjach mamy do czynienia z funkcjonowaniem pracodawcy (przeważnie spółki kapitałowej) w ramach złożonej organizacji gospodarczej, mającej zwykle faktyczny (niesformalizowany) charakter, takiej jak holding lub koncern ${ }^{39}$. Na szczeblu decyzyjnym dla całego zgrupowania inicjowane są działania, które mają na celu osiągnięcie określonych celów gospodarczych, w tym maksymalizację zysku. Działania ta-

36 Podobną funkcję pełni generalna regulacja art. $33^{1} \S 2$ k.c., proklamująca odpowiedzialność subsydiarną członka jednostki organizacyjnej niebędącej osobą prawną (osoby ustawowej) za zobowiązania tej jednostki, w razie jej niewypłacalności.

37 Analogiczne zasady odpowiedzialności stosują się do wspólników spółki partnerskiej i spółki komandytowej (z uwzględnieniem treści art. 111 k.s.h.), a także do komplementariusza w spółce komandytowo-akcyjnej.

38 Zbliżone uwagi można sformułować na tle art. 299 k.s.h., zastrzegając odmienność regulowanej w nim materii. Przepis ten pozwala bowiem na przypisanie odpowiedzialności za zobowiązania spółki kapitałowej (spółki z o.o.) osobie związanej z nią stosunkiem organizacyjnym (członkowi zarządu, a także likwidatorowi — art. $299^{1}$ k.s.h.), a nie właścicielskim, przewidziana zaś w nim odpowiedzialność subsydiarna ma charakter odszkodowawczy lub gwarancyjny.

39 O formach koncentracji gospodarczej przedsiębiorców zob. bliżej P. Czarnecki, op. cit., s. $35-46$. 
kie mogą godzić jednak w interesy osób trzecich, do których należą pracownicy, prowadząc do zaburzenia stosowania instytucji prawa pracy ${ }^{40}$.

Należy zauważyć, że to zjawisko nie ogranicza się do stosunków prawa pracy, ale występuje też w stosunkach prawa cywilnego, w których zostało wcześniej rozpoznane i ocenione w piśmiennictwie. Doktryna prawa cywilnego wskazuje, że z braku wyraźnej normy prawnej stanowiącej podstawę osobistej odpowiedzialności wspólnika za zobowiązania spółki kapitałowej słuszna aksjologicznie zasada związku odpowiedzialności z decyzją wspólnika - jako zasada pozanormatywna - przegrywa z normatywną zasadą braku tej odpowiedzialności. Jedynie na gruncie poszczególnych stanów faktycznych można podjąć próbę ,przekłucia welonu korporacyjnego" (przebicia zasłony odpowiedzialności prawnej), chroniącego wspólnika przed odpowiedzialnością za zobowiązania spółki kapitałowej, odwołując się przy tym do koncepcji nadużycia prawa, której zastosowanie jest jednak o tyle problematyczne, że nie powinna ona być bronią zaczepną, stosowaną przez stronę dochodzącą swojego uprawnienia, wynikającego ze stosunku prawnego łączącego ją ze spółką ${ }^{41}$.

Z punktu widzenia niniejszego opracowania istotny jest podział omawianych tutaj sytuacji na przypisanie pracodawcy skutków określonych działań dokonywanych w obrębie grupy spółek oraz przypisanie podmiotowi kapitałowemu odpowiedzialności za zobowiązania spółki-pracodawcy ${ }^{42}$. W orzecznictwie sądowym spotykamy się z przykładami skutecznego przypisania odpowiedzialności pracodawcy, jak zawarcia z pracownikiem przez różne spółki należące do grupy kilku umów o zatrudnienie, ze skutkiem pogorszenia sytuacji prawnej pracobiorcy ${ }^{43}$, a także w przypadku nierównego traktowania pracowników wykonujących tę samą pracę na rzecz poszczególnych spółek, jeżeli nierówność ta jest konsekwencją przeprowadzonych w ramach koncernu zmian organizacyjnych ${ }^{44}$.

Trudniej wskazać natomiast sytuacje, w których możliwe jest przypisanie odpowiedzialności wobec pracownika podmiotowi kapitałowemu. Próbując sformułować przykład przybliżający się do tak określonego założenia, można odwołać się do praktyki negocjowania przez zakładową organizację związkową z inwestorem strategicznym nienazwanego porozumienia zbiorowego (paktu socjalnego).

40 Typy takich działań przybliża M. Raczkowski, Pomijanie prawnej odrębności członków holdingu w indywidualnym prawie pracy, „Praca i Zabezpieczenie Społeczne” 2016, nr 8, s. 19-22 (cz. I), oraz „Praca i Zabezpieczenie Społeczne” 2016, nr 9, s. 11-18 (cz. II).

41 Zob. A. Szumański, [w:] System Prawa Prywatnego, t. 17A. Prawo spótek kapitałowych, red. S. Sołtysiński, Warszawa 2015, s. 848-852; A. Opalski, Problematyka pominięcia prawnej odrębności spótek kapitałowych, „Przegląd Prawa Handlowego” 2012, nr 8, s. 10-20.

42 Taki podział proponuje M. Raczkowski, nawiązując do literatury prawa cywilnego. Zob. idem, op. cit., cz. I, s. 18-19.

43 Zob. wyrok SN z dnia 5 listopada 2013 r., II PK 50/13, OSNP 2014, nr 9, poz. 129; wyrok SN z z dnia 17 marca 2015 r., I PK 179/14, OSNP 2016, nr 11, poz. 140.

44 Zob. wyrok SN z dnia 18 września 2014 r., III PK 136/13, OSNP 2016, nr 2, poz. 17. 
Według przeważającego orzecznictwa ${ }^{45}$, krytykowanego przez poważną część doktryny prawa pracy ${ }^{46}$, porozumienie takie może mieć charakter normatywny, regulując prawa i obowiązki stron indywidualnych stosunków pracy (art. 9 $\S 1$ k.p.). Natomiast reprezentując stanowisko, że pakt socjalny nie stanowi źródła prawa pracy, można upatrywać jego skuteczności dla pracownika w przepisach prawa cywilnego, traktując jego postanowienia jako umowę o świadczenie przez osobą trzecią (art. 391 k.c.). Inwestor zobowiązuje się zatem, że pracodawca spełni na rzecz pracownika określone świadczenie (na przykład podwyższoną odprawę z tytułu rozwiązania stosunku pracy), ze skutkiem odpowiedzialności odszkodowawczej inwestora, ponoszonej wobec pracownika w razie niewywiązania się przez pracodawcę z tego zobowiązania ${ }^{47}$. Niezależnie od tego nie można wykluczyć skorzystania przez pracownika $\mathrm{w}$ innych sytuacjach $\mathrm{z}$ uniwersalnego rozwiązania, polegającego na pociągnięciu wspólnika pracodawcy do odpowiedzialności deliktowej za działania wywołujące szkodę u pracownika, czego warunkiem jest jednak wykazanie przesłanek czynu niedozwolonego (art. 415 i następne k.c.) ${ }^{48}$.

Wydaje się natomiast, że innego rodzaju przypisanie odpowiedzialności pracodawczej podmiotowi kapitałowemu może pojawić się w sferze zbiorowych stosunków pracy. Wiąże się to z wyprowadzeniem przez Sąd Najwyższy z normy art. 59 ust. 2 Konstytucji RP pojęcia pracodawcy konstytucyjnego. Według tego stanowiska w sensie konstytucyjnym stronę pracodawczą rokowań zbiorowych należy rozumieć szerzej niż pracodawcę w rozumieniu art. 3 k.p. Nie ma zatem powodu, aby wyłączyć poza zakres tak rozumianej strony na przykład centralny zarząd grupy przedsiębiorstw czy inwestora, który ma nabyć akcje ${ }^{49}$. Stojąc na gruncie tego kierunku orzecznictwa, inwestor zawierający nienazwane porozumienie zbiorowe (pakt socjalny), które stanowi źródło prawa pracy dla danego pracodawcy (art. 9 § 1 k.p.), będzie uczestniczył, jako strona tego porozumienia, w zbiorowych stosunkach pracy, ponosząc ewentualną odpowiedzialność wobec drugiej strony rokowań zbiorowych.

45 Zob. przede wszystkim wyrok SN z dnia 12 sierpnia 2004 r. III PK 38/04, OSNP 2005, nr 4, poz. 55; oraz uchwałę składu siedmiu sędziów SN z dnia 23 maja 2006 r., III PZP 2/06, OSNP 2007, nr 3-4, poz. 38 .

46 Krytykę taką wyrażono między innymi w glosach do wskazanego w poprzednim przypisie wyroku SN z dnia 12 sierpnia 2004 r., III PK 38/04; glosy: A. Tomanka („Orzecznictwo Sądów Polskich” 2005, nr 7-8, poz. 87), A. Góry-Błaszczykowskiej („Monitor Prawa Pracy”, wkładka, 2005, nr 10, poz. 23) i M. Tomaszewskiej („Gdańskie Studia Prawnicze — Przegląd Orzecznictwa” 2005, nr 3, poz. 19).

47 Odnotowując krytykę zastosowania art. 391 k.c. jako instrumentu zmierzającego do nadania postanowieniom porozumienia nienazwanego skuteczności w stosunkach pracy (zob. B. Wagner, Pakiet socjalny, PiZS 2006, nr 9, s. 7-9), należy uznać, że w rozpatrywanym tutaj przypadku krytyka ta ma słabsze podstawy, jako że powstałe w ten sposób zobowiązanie inwestora będzie miało charakter cywilnoprawny.

$48 \mathrm{Na}$ ten temat zob. więcej M. Raczkowski, op. cit., cz. II, s. 15-17.

49 Tak Sąd Najwyższy we wskazanej uchwale składu siedmiu sędziów z dnia 23 maja 2006 r., III PZP 2/06. 
W tym kontekście można ponownie wskazać na przepis art. $241^{28} \mathrm{k} . p$., przewidujący że zakładowy układ zbiorowy pracy może obejmować więcej niż jednego pracodawcę, jeżeli pracodawcy ci wchodzą w skład tej samej osoby prawnej. Część autorów upatruje w tym przepisie podstawy do zawarcia układu zbiorowego w złożonych strukturach o charakterze holdingowym bądź koncernowym, w których występuje powiązanie kapitałowe pracodawców-spółek zależnych ze spółką dominującą ${ }^{50}$. Wyrażając sceptycyzm wobec tak rozszerzającej wykładni art. $241^{28}$ $\S 1$ k.p., która ignoruje przeciwną jej treść tego przepisu ${ }^{51}$, nie można nie dostrzec, że w jej wyniku spółka dominująca staje się podmiotem praw i obowiązków wynikających ze statusu podmiotu negocjującego układ, na mocy którego kształtowane są stosunki prawne między spółkami zależnymi i ich pracownikami.

W piśmiennictwie sformułowano też pogląd, że spółka dominująca może korzystać z odcinkowej zdolności pracodawczej przy prowadzeniu sporu zbiorowego pracy dotyczącego spółki zależnej ${ }^{52}$, oddziałując na przebieg tego sporu przez działania władcze i niewładcze, podejmowane odpowiednio wobec członków zarządu spółek zależnych oraz wobec związków zawodowych ${ }^{53}$. Z kolei na tle rozwiązań prawnych przewidujących zasady partycypacji pracowniczej w przedsiębiorstwach transnarodowych, a zwłaszcza w ramach spółki europejskiej ${ }^{54}$, wskazuje się, że holdingowa spółka europejska staje się podmiotem zbiorowych stosunków pracy. Trudno bowiem rozdzielić formalnego pracodawcę pracowników od spółki europejskiej w zakresie prawa pracowników do uzyskania informacji i udziału w konsultacjach, które odnoszą się do spraw i decyzji dotyczących funkcjonowania poszczególnych spółek, grupy kapitałowej lub spółki europejskiej jako takiej ${ }^{55}$.

Przypisanie w przedstawionych sprawach, należących do zbiorowego prawa pracy, odpowiedzialności pracodawczej podmiotowi kapitałowemu wynika jednak

50 Tak K.W. Baran, Zakładowy układ zbiorowy pracy obejmujący pracodawców wchodzacych w sktad tej samej osoby prawnej, [w:] Z aktualnych zagadnień prawa pracy i zabezpieczenia społecznego. Księa jubileuszowa Profesora Waleriana Sanetry, red. B. Cudowski, J. Iwulski, Białystok 2013, s. 57-60; J. Piątkowski, [w:] Kodeks pracy. Komentarz, red. K.W. Baran, Warszawa 2016, s. 1450-1451.

51 Przepis art. $241^{28} \S 1$ k.p. zakłada wejście przez pracodawców w skład, „tej samej osoby prawnej”, zawierającej układ. Natomiast posiadanie udziałów w spółce zależnej przez spółkę dominującą nie oznacza wejścia przez tę pierwszą spółkę w skład spółki dominującej.

52 Z. Kubot, Odcinkowa zdolność pracodawcza spótki dominujacej w grupie kapitałowej, „Praca i Zabezpieczenie Społeczne” 2014, nr 9, s. 17-23.

53 Z. Kubot, Rola spótki dominującej w sporze zbiorowym pracowników spótki zależnej. Część II, „Praca i Zabezpieczenie Społeczne” 2014, nr 12, s. 16-17.

54 Rozwiązania te zawierają przepisy tytułu IV ustawy z dnia 4 marca 2005 r. o europejskim zgrupowaniu interesów gospodarczych i spółce europejskiej (tekst jedn. DzU z 2015 r. poz. 2142), które implementują postanowienia dyrektywy nr 2001/86/WE z dnia 8 października 2001 r. uzupełniającej statut spółki europejskiej w odniesieniu do zaangażowania pracowników (Dz. Urz. WE L 294 z dnia 10 listopada 2001 r.).

55 Zob. uwagi zgłoszone przez P. Czarneckiego, op. cit., s. 224-230; a także przez Ł. Pisarczyka, Ryzyko pracodawcy, Warszawa 2008, s. 39. 
nie $\mathrm{z}$ tego, że skorzystano wyjątkowo z koncepcji przebicia zasłony odpowiedzialności prawnej, ale że podmiotowi temu przyznaje się niektóre kompetencje pracodawcze, które realizuje on obok pracodawcy w rozumieniu art. 3 k.p. ${ }^{56}$ Możliwa jest również nieco odmienna ocena wskazująca, że punktem odniesienia w kolektywnych stosunkach pracy jest szerzej pojęta strona pracodawcza, w której uczestniczy podmiot kapitałowy uprawniony do podjęcia określonych działań oraz ponoszący z tego tytułu odpowiedzialność przewidzianą zarówno w uregulowaniach należących do prawa pracy, jak i przepisach prawa cywilnego ${ }^{57}$. Niezależnie jednak od przyjętego w tym zakresie szczegółowego założenia można zauważyć, że o ile w indywidualnych stosunkach pracy odpowiedzialność inwestora lub spółki dominującej może być im przypisana za pośrednictwem instrumentów prawa cywilnego ${ }^{58}$, o tyle w zbiorowych stosunkach pracy ustalenie tej odpowiedzialności następuje za pomocą wykładni przepisów zbiorowego prawa pracy.

\section{PODSUMOWANIE}

Przeprowadzone rozważania uzasadniają stanowisko, że analiza prawna odpowiedzialności pracodawcy w stosunkach prawa pracy nie może ograniczać się, pod względem podmiotowym, do pracodawcy w znaczeniu nadanym art. 3 k.p. W ramach pojęcia odpowiedzialności pracodawcy należy uwzględniać nie tylko podmiot aktualnie zatrudniający pracownika, lecz także podmiot, który był pracodawcą, ale utracił ten status na skutek przekazania zakładu pracy lub jego części albo innego przekształcenia organizacyjno-prawnego. Ponadto w kategoriach odpowiedzialności pracodawczej należy rozpatrywać odpowiedzialność ponoszoną przez macierzystą osobę prawną z tytułu zobowiązań podjętych przez jej wewnętrzną jednostkę organizacyjną, nieposiadającą osobowości prawnej (pracodawcę wewnętrznego). Dla takiej oceny nie jest bez znaczenia tendencja do zakresowego uwzględniania podmiotowości prawnej pracodawcy „właścicielskiego", która zaznacza się nie tylko w wypowiedziach doktrynalnych, lecz także w orzecznictwie i treści niektórych aktów normatywnych.

Większe wątpliwości wywołuje odpowiedzialność spółki dominującej, kluczowego wspólnika (inwestora strategicznego) lub innego podmiotu kapitałowego działającego w obrębie organizacji złożonej, do której należy pracodawca będący

56 Podobnie P. Czarnecki, op. cit., s. 221-222.

57 Wbrew sceptycznemu stanowisku orzecznictwa literatura przedmiotu dopuszcza sankcjonowanie obligacyjnych postanowień porozumienia zbiorowego na drodze odwołania się do przepisów kodeksu cywilnego (art. 300 k.p.). Zob. L. Florek, Ustawa i umowa w prawie pracy, Warszawa 2010, s. 329-338; Z. Hajn, Zbiorowe prawo pracy. Zarys systemu, Warszawa 2013, s. 161-163.

58 W ocenie M. Raczkowskiego (op. cit., cz. I, s. 18-19) podstawą tych zobowiązań mogą być wyłącznie instrumenty prawa cywilnego, jako że podmiot kapitałowy nie jest stroną indywidualnych stosunków pracy. 
osobą prawną lub osobą ustawową. Uzasadnione jest selektywne podejście do tej kwestii. Jako odpowiedzialność pracodawczą należy kwalifikować sytuacje, w których regulacje prawne uzasadniają tezę o nadaniu podmiotowi kapitałowemu uprawnień do działania w stosunkach prawa pracy po stronie pracodawczej. W świetle obecnego stanu prawnego możliwości takie zdają się rysować w dziedzinie zbiorowego prawa pracy, aczkolwiek wnioski nie mogą być generalizowane i wyciągane zbyt pochopnie. Przeciwnie, pożądana jest wnikliwa analiza poszczególnych konstrukcji prawnych, która musi być dokonywana de lege lata.

Natomiast poza zakresem pojęcia odpowiedzialności pracodawczej, rozumianej nawet w szerokim znaczeniu tego słowa, sytuują się przypadki odpowiedzialności podmiotu kapitałowego, ponoszonej na podstawie przepisów prawa cywilnego, w tym zwłaszcza przy ewentualnym zastosowaniu koncepcji przebicia podmiotowości prawnej, która na obecnym etapie rozwoju stosunków prawnych nosi znamiona ekstraordynaryjności. Zastosowanie tej koncepcji nie prowadzi bowiem do podważenia odrębnej podmiotowości i odpowiedzialności wspólnika (lub innego nosiciela praw majątkowych do mienia podmiotu zatrudniającego) oraz pracodawcy. Podobne wnioski odnoszą się do odpowiedzialności wspólników osobowych spółek handlowych oraz nabywcy przedsiębiorstwa (art. $55^{4}$ k.c.), wywodzonej z przepisów prawa cywilnego, a także do odpowiedzialności instytucji gwarancyjnej za świadczenia pracownicze niezaspokojone w związku z niewypłacalnością pracodawcy. Jednocześnie należy zaznaczyć, że odpowiedzialność tego kręgu podmiotów pozostaje w związku z odpowiedzialnością pracodawcy, wobec czego nie powinna być pomijana przy badaniu problematyki odpowiedzialności w prawie pracy.

\section{ENTITIES OF EMPLOYER'S RESPONSIBILITY IN EMPLOYMENT RELATIONS}

\section{Summary}

This text is focused on the issue of an employer treated as a subject of the responsibility in labour law relations. The labour law doctrine shows that the responsibility of an employer for an infringement of its obligations may be analysed in a wide sense which is not limited to the responsibility of an employer as defined in article 3 of Polish Labour Code. The other legal or natural persons which bear responsibility with an employer or instead of it must be taken into account. To this aim the author reviews the responsibility of some legal and natural persons: a leading partner of a company acting as an employer, the Guaranteed Workers' Benefits Fund and a legal person in the context of obligations of its organizational unit which is an employer according to article 3 of Polish Labour Code. Above-mentioned situations are of a heterogeneous nature. Therefore it is impossible to apply to them the unified rules of legal evaluation. In some cases it may be stated that a named subject bears responsibility which is characteristic for the employer's party of labour relations (e.g. a legal person which answers for the obligations of its organizational unit being an 
employer). In other cases we deal with a type of responsibility which comes beyond the scope of the notion of employer's party responsibility but this does not mean that it should not be a subject of a discussion on the notion of responsibility in labour law.

Keywords: labour responsibility, employer

\section{BIBLIOGRAFIA}

Baran K.W., Zakładowy układ zbiorowy pracy obejmujacy pracodawców wchodzacych w sktad tej samej osoby prawnej, [w:] Z aktualnych zagadnień prawa pracy i zabezpieczenia spolecznego. Ksiega jubileuszowa Profesora Waleriana Sanetry, red. B. Cudowski, J. Iwulski, Białystok 2013.

Chałfina R.O., Ogólna nauka o stosunku prawnym, Warszawa 1979.

Czarnecki P., Odpowiedzialność pracodawcy a rozwój struktur holdingowych, Warszawa 2014.

Dybowski T., [w:] System prawa cywilnego, t. 3, cz. 1. Prawo zobowiązań - część szczegółowa, red. Z. Radwański, Wrocław 1981.

Florek L., Ustawa i umowa w prawie pracy, Warszawa 2010.

Frąckowiak J., Jednostka organizacyjna jako podmiot stosunku pracy, [w:] Z zagadnień prawa pracy i prawa socjalnego. Ksiega jubileuszowa Profesora Herberta Szurgacza, red. Z. Kubot, T. Kuczyński, Warszawa 2011.

Gersdorf M., Niewypłacalność pracodawcy w prawie pracy, Warszawa 2002.

Góra-Błaszczykowska A., Glosa do wyroku SN z 12 sierpnia 2004 r., III PK 38/04, „Monitor Prawa Pracy", wkładka, 2005, nr 10, poz. 23.

Hajn Z., [w:] System Prawa Pracy, t. 2. Indywidualne prawo pracy, red. G. Goździewicz, Warszawa 2017.

Hajn Z., Odpowiedzialność prawna zakładu pracy w zbiorowych stosunkach pracy, [w:] Odpowiedzialność zbiorowych podmiotów prawa pracy. Materiały XIV Zimowej Szkoty Prawa Pracy, red. W. Sanetra, Wrocław 1987.

Hajn Z., Zbiorowe prawo pracy. Zarys systemu, Warszawa 2013.

Klein A., Wykonanie umowy i odpowiedzialność, [w:] Instytucje prawne w gospodarce narodowej, red. L. Bar, Wrocław 1981.

Kubot Z., Odcinkowa zdolność pracodawcza spółki dominującej w grupie kapitałowej, „Praca i Zabezpieczenie Społeczne" 2014, nr 9.

Kubot Z., Rola spótki dominującej w sporze zbiorowym pracowników spótki zależnej. Część II, „Praca i Zabezpieczenie Społeczne” 2014, nr 12.

Lang W., Struktura odpowiedzialności prawnej, „Zeszyty Naukowe Uniwersytetu Mikołaja Kopernika w Toruniu. Prawo" 1967.

Latos-Miłkowska M., Ochrona roszczeń pracowniczych w razie niewypłacalności pracodawcy. Komentarz, Warszawa 2017.

Masternak Z., Oceny w odpowiedzialności pracowniczej, [w:] Odpowiedzialność zbiorowych podmiotów prawa pracy. Materiały XIV Zimowej Szkoty Prawa Pracy, red. W. Sanetra, Wrocław 1987.

Opalski A., Problematyka pominięcia prawnej odrębności spółek kapitałowych, „Przegląd Prawa Handlowego" 2012, nr 8.

Paczuski R., Prawo ochrony środowiska, Bydgoszcz 2000.

Piątkowski J., [w:] Kodeks pracy. Komentarz, red. K.W. Baran, Warszawa 2016.

Pisarczyk Ł., Przejście zakładu pracy na innego pracodawce, Warszawa 2013. 
Pisarczyk Ł., Ryzyko pracodawcy, Warszawa 2008.

Raczkowski M., Pomijanie prawnej odrębności członków holdingu w indywidualnym prawie pracy, „Praca i Zabezpieczenie Społeczne” 2016, nr 8, s. 19-22 (cz. I), oraz „Praca i Zabezpieczenie Społeczne" 2016, nr 9, s. 11-18 (cz. II).

Radecki W., Odpowiedzialność prawna w ochronie środowiska, Warszawa 2002.

Rączka K., [w:] Kodeks pracy. Komentarz, M. Gersdorf, K. Rączka, M. Raczkowski, Warszawa 2014.

Sanetra W., O pojęciu i zakresie odpowiedzialności pracowniczej, [w:] Odpowiedzialność pracownicza. Materiały XI Zimowej Szkoły Prawa Pracy, red. W. Sanetra, Wrocław 1984.

Sanetra W., Odpowiedzialność wedtug prawa pracy. Pojęcie, zakres, dyferencjacja, Wrocław 1991.

Sanetra W., Odpowiedzialność za naruszenie norm prawa pracy w warunkach demokracji i spotecznej gospodarki rynkowej, [w:] Prawo pracy RP w obliczu przemian, red. M. Matey-Tyrowicz, T. Zieliński, Warszawa 2006.

Siemiątkowski T., [w:] System Prawa Prywatnego, t. 16. Prawo spółek osobowych, red. A. Szajkowski, Warszawa 2008.

Stelmachowski A., Wstep do teorii prawa cywilnego, Warszawa 1984.

Szumański A., [w:] System Prawa Prywatnego, t. 17A. Prawo spółek kapitałowych, red. S. Sołtysiński, Warszawa 2015.

Tomanek A., Glosa do wyroku SN z 12 sierpnia 2004 r., III PK 38/04, OSP 2005, nr 7-8, poz. 87.

Tomanek A., Przejście zakładu pracy na innego pracodawcę, Wrocław 2002.

Tomanek A., Stosunki pracy w razie likwidacji i upadtości pracodawcy, Warszawa 2012.

Tomaszewska M., Glosa do wyroku SN z 12 sierpnia 2004 r., III PK 38/04, „Gdańskie Studia Prawnicze - Przegląd Orzecznictwa" 2005, nr 3, poz. 19.

Wagner B., Pakiet socjalny, PiZS 2006, nr 9, s. 7-9. 